\title{
Effects of Seasonal Factors in The Goats' Reproductive Efficiency
}

\author{
Usman Mir Khan",a, Ali Murad Khan²,b, Umar Murad Khan²,c, Zeliha Selamoglu, 3,,* \\ ${ }^{I}$ Department of Dairy Technology, Faculty of Animal Production and Technology, University of Veterinary and Animal Sciences, \\ Lahore,54000, Pakistan \\ ${ }^{2}$ Doctor of Veterinary Medicine, Riphah College of Veterinary Sciences, Lahore,54000, Pakistan \\ ${ }^{3}$ Department of Medical Biology, Faculty of Medicine, Niğde Ömer Halisdemir University, Campus, 51240 Niğde, Turkey
}

*Corresponding author

\begin{tabular}{l|l}
\hline A R T I C L E I N F O & A B S T R A C T \\
\hline Review Article & $\begin{array}{l}\text { Interest in goat farming is at its peak since the last decade of 20th century because the role of goat is } \\
\text { well established in animal protein as well as in economic uplift of poor masses in the tropics and } \\
\text { subtropics, but also constitutes an important component of traditional farming systems. Goat is a } \\
\text { better option as farm animal in the tropics and subtropics as it can withstand dehydration and has } \\
\text { better browsing habit which enables it to survive where cattle and sheep farming is difficult. } \\
\text { Reproductive performance of does is of immense importance as contributing factor towards } \\
\text { increased meat production and in finding out more prolific animals. This is the main factor affecting } \\
\text { productivity of goats. Therefore, an improved reproduction rate will be an approach to increase in }\end{array}$ \\
$\begin{array}{l}\text { Received : } 17 / 08 / 2019 \\
\text { Accepted : } 30 / 09 / 2019\end{array}$ & $\begin{array}{l}\text { advantages for birth and offspring survival and development, as lambing/kidding coincides with } \\
\text { good weather and maximum availability of forage. It is believed that photoperiod is the } \\
\text { environmental factor other than food availability that determines the sexual activity in sheep and } \\
\text { goat. This review paper focuses on the general aspects of seasonal factors influencing the goat's } \\
\text { reproductive efficiency. }\end{array}$ \\
$\begin{array}{l}\text { Geywords: } \\
\text { Seasonal factors } \\
\text { Reproductive performance } \\
\text { Animal } \\
\text { Sheep }\end{array}$ &
\end{tabular}

Keywords:

Goat

Reproductive performance

Sheep

Interest in goat farming is at its peak since the last decade of 20th century because the role of goat is subtropics, but also constitutes an important component of traditional farming systems. Goat is a better option as farm animal in the tropics and subtropics as it can withstand dehydration and has better browsing habit which enables it to survive where cattle and sheep farming is difficult. Reproductive performance of does is of immense importance as contributing factor towards numbers. Reproductive seasonality represents a natural adaptation that provides important advantages for birth and offspring survival and development, as lambing/kidding coincides with weather and maximum availability of forage. It is believed that photoperiod is the goat. This review paper focuses on the general aspects of seasonal factors influencing the goat's reproductive efficiency.

\section{Introduction}

Goats are found in almost all ecological zones of tropics and subtropics i.e arid, semiarid, humid and sub humid but major population of goats is found in dry tropical and subtropical areas mainly due to poor agricultural production (Jahnke, 1982; Peters, 1988; Lebbie and Ramsay, 1999; Morand-Fehr and Boyazoglu, 1999 and Iniguez, 2004). The increased efficiency of small ruminants is defined as an increased ratio of output (lifetime production) to input (labour, feed, and management costs). Life time production is measured in terms of main products from goats viz. meat, milk and fiber in case of some special breeds. High reproductive rate has significant impact on efficiency of production, which means more animals for sale as meat and a higher selection differential leading to a faster response to selection. The most important tool for enhanced reproductive efficiency is accelerated kidding which can be defined as three kidding in two years or five kidding in three years.
Management conditions, in which the animals are reared, are also important factors to govern the success of accelerated kidding. The goats planned to kid thrice in two years through synchronization, importantly result in higher meat production particularly during anestrus (Schneider and Stanko, 2005). Seasonal breeding is one of the obstacles for year round continuous supply of goat and goat products. Many breeds of goats show a distinct breeding pattern during a year (Restall, 1992; Delgadillo et al., 1999; Rivera et al., 2003). Reproductive seasonality represents a natural adaptation that provides important advantages for birth and offspring survival and development, as lambing/kidding coincides with good weather and maximum availability of forage (Ungerfeld, 2003). Food availability controls the timing of the annual ovulatory period in subtropical and tropical latitudes (Bronson, 1989; Asher et al., 1999; Walkden-Brown and Bocquier, 2000). However, the female goats reared indoors with well- 
nourished conditions still exhibited seasonality in reproduction (Restall, 1992; Rivera et al., 2003; Duarte et al., 2008). It is believed that photoperiod is the environmental factor other than food availability that determines the sexual activity in sheep and goat (Delgadillo et al., 2004; Malpaux, 2006; Chemineau et al., 2004; Duarte et al., 2010; Delgadillo et al., 2011). A trial was designed to find out wheither or not exogenous gonadotropin releasing hormone $(\mathrm{GnRH})$ improves the onset of estrus in dwarf goats. It was found that GnRH had non-significant effect on the onset of estrus. Moreover, treatment by GnRH improved the synchrony of the surge (Pierson et al., 2003). In dairy Awassi ewes, synchronization protocols were used during out of breeding season. It was observed that gonadotropin releasing hormone, prostaglandin $\mathrm{F} 2$ alpha and gonadotropin releasing hormone (GPG) protocol could only be effective when used near to the natural breeding season (Faigl et al., 2008). It was concluded that progestagen supplement could be safely used to improve reproductive performance of ewes being bred out of season (Husein and Abahneh, 2008). The injection of PGF2 alpha in Awassi ewes reduced the induction of estrus-onset and estrus-end time gap with progestagen-PMSG (Turk et al., 2008). Super ovulation was induced in Nubian and Nubian crossbred dairy goats with follicle stimulating hormone (FSH) and prostaglandin. It was concluded that $\mathrm{GnRH}$ is effective for super ovulation in conjunction with FSH (Krisher et al., 1994). While studying stimulation of estrus behaviour in goats by continuous or discontinuous exposure to males, the results indicated that while at grazing conditions, the anestrus goats may show estrus behaviour when opened to a buck treated with artificial long days (Rivas-Muñoz et al., 2007). It was found that Sarda ewes responded to the ram effect and $80 \%$ of ewes in one group were conceived at first ovulation. It was concluded that priming of lactating Sarda ewes in spring with progesterone $(\mathrm{P} 4)+\mathrm{PMSG}$ before ram effect, is an effective way to induce fertile ovulations (Todini et al., 2007). However, the age of ram is an important factor to be kept in mind while studying the ram effect. It was investigated that yearling rams which were used previously for breeding proved better than unused yearling rams (Kenyon et al., 2007). The reproductive performance in an accelerated lambing system of 3 lambing in 2 years was evaluated. The ewes in each group were kept under study for three reproductive cycles. They observed that the fertility rate in the ewes treated with photoperiod was $91.6 \%$, which is quite similar with the fertility as observed in natural breeding season. It was pointed out that ewes kept under the photoperiod schedule gave 1.38 lambing / year and $69 \%$ of these ewes lambed three times in two years (Cameron et al., 2010). Reproductive performance of does is of immense importance as contributing factor towards increased meat production and in finding out more prolific animals. This is the main factor affecting productivity of goats. Therefore, an improved reproduction rate will be an approach to increase in numbers. The reproductive efficiency means the net kid crop reared up to weaning. The lambing season and effect of environment on ewe performance in accelerated (January, May and September) or annual (April) lambing were analysed. It was reported that fertility for annual April was found to be on higher side as compared to accelerated May or January and it was slightly low for September lambing. During the month of April, the litter size noted was 1.9 as compared to January i.e.1.8, or May 1.7 and 1.4 for the month of September along with lower mortality \% in young kids. However, the mean weaning weights were decreased in the larger April and May kids. The weights of lambs weaned/ewe exposed were increased for annual April as compared to May and January lambing and found to be lower for September lambing. When the ewes were treated with hormone for September lambing, the fertility was increased from $16 \%$ to $44 \%$ along with litter size from 1.6 to 1.8 (Fogarty et al., 1984).

It was found that the polled Dorset ewes which were separated from rams in late winter/early spring showed a decreased proportion of ewes ovulating from September to November, showed a high proportion in December, without changing the ovulation rate. They concluded that the variation in reproductive measures during spring season indicates a scope for selection and improvements in spring joining results due to ram effects in Dorset ewes may be possible (Hall et al., 1986). When the breeding performance of Damascus goats was evaluated, it was concluded that supplemental feeding was required to increase production of goats in arid or semi-arid environment. It was found that kidding percentage and birth weight of kids didn't differ significantly among groups. Moreover, the number of kids weaned/doe kidding and weight of kids weaned/doe kidding were significantly higher for group of animals fed bar seem clover hay. However, mean body weight of kids at birth and at weaning were found significantly less for control group (Shetaewi et al., 2001). When the reproductive performance was checked in estrus-induced nulliparous Saanen and Alpine dairy goats, it was found that rate of parturition, litter size and gestation period were similar in goats treated with different treatments, also breeding did not considerably improve reproductive performance (Fonseca et al., 2005). Weekly growth curve was determined and it was found that lambs borne in dry season were the heaviest. However, the single as well as male lambs were also heavier. Moreover, it was noted that the ewes in 3rd and 4th parity produced heavier lambs, growing with averagely higher daily gains (Gbangboche et al., 2006). It was found that litter size was increased with age and parity. However, lamb birth weight was affected by the season (Ali et al., 2009). The research was carried out for a period of one year to investigate the productive and reproductive performance of Malpura ewes. Allometric parameters were taken in this research period. It was found that BCS has strong positive impact on allometric measurements and reproductive parameters (Sejian et al., 2009).

It was reported that the mortality rate was 4, 15.3, 19.4 and $28 \%$ in goats (Mellado et al., 2008), in Norwegian goats (Engeland et al., 1999), in kids (Borde et al., 2006) and kids (Abubakar et al., 2008), respectively. Two accelerated lambing systems were compared, in which early lambing was found to be associated with higher rates of perinatal mortality ( $\mathrm{P}>0.05)$ (Iniquez et al., 1986). It was found that the preweaning lamb mortality was $37 \%$ in Javanese thin tail ewes (Chaniago et al., 1988), respectively. 


\section{Conclusion}

Reproductive seasonality represents a natural adaptation that provides important advantages for birth and offspring survival and development, as lambing/kidding coincides with good weather and maximum availability of forage. It is believed that photoperiod is the environmental factor other than food availability that determines the sexual activity in sheep and goat.

\section{Acknowledgements}

The authors are grateful to Department of Dairy Technology Postgraduate Laboratory of University of Veterinary and Animal Sciences, Pakistan for providing research facilities and their excellent technical assistance.

\section{Disclosure statement}

No potential conflict of interest was reported by the authors.

\section{Availability of data and materials}

All data are included in the article.

\section{References}

Ali A, Hayder M, Derar, R. 2009. Reproductive performance of Farafra ewes in the subtropics. Anim Reprod Sci. 114(4): 356-361.

Ali A, Khan MS. 2008. Environmental factors affecting growth and reproductive traits of Beetal goats in Pakistan. Ind. J Anim Genet Breed. 27: 26-37.

Al-Shorepy SA, Alhadrami GA, Abdulwahab K. 2002. Genetic and phenotypic parameters for early growth traits in Emirati goat. Small Rumin Res. 45(3): 217-223.

Amin MR, Hussain SS, Islam ABMM. 2001. Reproductive peculiarities and litter weight in different genetic groups of Black Bengal does. Asian-Aust. J Anim Sci. 14(3): 297-301.

Anandana S, Sastry VRB, Musalia LM, Agrawal DK. 1996. Growth rate and nutrient efficiency of growing goats fed urea ammoniated neem (Azadirachta indica) seed kernel meal as protein supplement. Small Rumin Res. 22(3): 205-212.

Anderson GB, Ruffing NA, BonDurant RH, Pashen RL. 1991. Preliminary observations on reproduction in a female sheepgoat chimaera. Vet Rec. 129 (21): 467-469.

Boland MP, Scaramuzzi RJ, Hoskinson RM, Nancarrow CD, Murray JD, Hazelton IG, Sutton R. 1987. Ovarian response to PMSG and GnRH in ewes immunised against oestradiol17 beta. Vet Rec. 120 (25): 590-592.

Boly H, Miaro L, Tamboura H, Sawadogo L, Sulon J, Beckers JF, Leroy P. 2000. Estrus synchronization in Djalonké var. "Mossi" ewes: comparison of hormonal treatment and ram effect. Tropicultura. 18(4): 177-180.

Borde G, Lowhar G, Adesiyun AA. 2006. Toxoplasma gondii and Chlamydophila abortus in caprine abortions in Tobago: a sero-epidemiological study. J Vet Med B Infect Dis Vet Public Health. 53(4): 188-193.

Bronson FH. 1989. Food as approximate factor: neuroendocrine pathways. In: Mammalian Reproductive Biology. The University of Chicago Press. pp: 60-89.

Brown BW, Cognie Y, Chemineau P, Poulin N, Salama OA. 1988. Ovarian capillary blood flow in seasonally anoestrus ewes induced to ovulate by treatment with GnRH. J Reprod Fertil. 84 (2): 653-658.
Brown MA, Jackson WG. 1995. Ewe productivity and subsequent preweaning lamb performance in St. Croix sheep bred at different times during the year. J Anim Sci. 73: 1258-1263.

Delgadillo JA, Flores JA, Veliz FG, Duarte G, Vielma J, Hernandez H, Fernandez IG. 2006. Importance of the signals provided by the buck for the success of the male effect in goats. Reprod Nutr Dev. 46(4): 391-400.

Delgadillo JA, Flores JA, Véliz FG, Hernández HF, Duarte G, Vielma J, Poindron P, Chemineau P, Malpaux B. 2002. Induction of sexual activity in lactating anovulatory female goats using male goats treated only with artificially long days. J Anim Sci. 80: 2780-2786.

Deligiannis C, Valasi I, Rekkas CA, Goulas P, Theodosiadou E, Lainas T, Amiridis GS. 2005. Synchronization of ovulation and fixed time intrauterine insemination in ewes. Reprod Domest Anim. 40 (1): 6-10.

DeNicolo G. 2007. Accelerated and out-of-season lamb production in New Zealand. PhD Thesis, Massey University, Palmerston North New Zealand.

DeNicolo G, Morris ST, Kenyon PR, Morel PC, Parkinson TJ. 2008. Melatonin-improved reproductive performance in sheep bred out of season. Anim Reprod Sci. 109 (1-4): 124133.

Devendra C. 1990. Goats. In: Introduction to animal husbandry in tropic and subtropics. Pyne, W.J.A., (Ed), 4th Edit., Blackwell Sci. Ltd. U.S.A. Pp: 505.

Dhara KC, Ray N, Roy S, Samanta AK, Senapati PK. 2008. Improvement of reproductive performances of Black Bengal goat through selection under field conditions. J Anim Vet Adv.7 (5):599-603.

Duarte G, Nava-Hernández MP, Malpaux B, Delgadillo JA. 2010. Ovulatory activity of female goats adapted to the subtropics is responsive to photoperiod. Anim Reprod Sci. 120: 65-70.

Iniguez LC, Quaas RL, Van Vleck LD. 1986. Lambing performance of Morlam and Dorset ewes under accelerated lambing systems. J Anim Sci. 63(6):1769-1778.

Jabbar MA, Anjum MI. 2008. Effect of diets with different forage to concentrate ratio for fattening of lohi lambs. Pak Vet J. 28(3): 150-152.

Jagtap DZ, Khutal BB, Yadav HS, Belhe ND. 1990. Genetic and non-genetic factors affecting birth weight in local, Angora and their crossbred goats. Ind J Anim Sci. 60(6):739-742. (Anim. Breed. Abst. 58:7986, 1990).

Jahnke, HE. 1982. Livestock Production Systems and Livestock Development in Tropical Africa. Kieler Wissenschaftsverlag Vauk, Kiel. Pp:1-253.

Javed K, Hussain SM, Afzal M. 2004. Studies on ram effect in Lohi sheep. Pak Vet J. 24(1):52-53.

Jenkins TG. 1986. Postweaning performance and carcass characteristics of crossbred ewe lambs produced in accelerated or annual lambing systems. J Anim Sci. 63(4):1063-1071.

Jingar SC, Pathodiya OP, Gurjar SB. 2005. Pre-weaning growth in Sirohi kids under field conditions. In: Proc. 8th National Conf Anim Genet and Breed. 8-10 March, Mathura, UP, India.

Kale MM, Tomer OS.1999 . Reproductive performance of crossbred goat flock under stall fed condition. Ind. J Small Rumin. 5(1): 20-24.

Kataktalware MA, Singh C, Gupta AK. 2004. First lactation reproductive performance of crossbred dairy goats under stall fed conditions. Ind. J Small Rumin. 10(2): 104-107.

Kausar R, Khanum SA, Hussain M, Shah MS. 2009. Estrus synchronization with medroxyprogesterone acetate impregnated sponges in goats (Capra hircus). Pak J Vet. 29(1): 16-18.

Kenyon PR, Morel PC, Morris ST, West DM. 2007. Effect of the age of rams on reproductive performance of ewe hoggets. New Zealand Vet J. 55940: 184-187. 
Khalifa TA, El-Saidy BE. 2006. Pellet-freezing of Damascus goat semen in a chemically defined extender. Anim. Reprod. Sci., 93 (3-4): 303-315.

Turk G, Gur S, Sonmez M, Bozkurt T, Aksu EH, Aksoy H. 2008. Effect of exogenous GnRH at the time of artificial insemination on reproductive performance of Awassi ewes synchronized with progestagen-PMSG-PGF2alpha combination. Reprod Domest Anim. 43(3): 308-313.

Ungerfled R, Dago L, Rubianes E, Forsberg M. 2004. Response of anestrus ewes to the ram effect after follicular wave synchronization with a single dose of estradiol-17 $\beta$. Reprod Nutr Dev. 44(1): 89-98.

Ungerfeld R, Gonza lez-Pensado S, Dago AL, Vilarin M, Menchaca A. 2007. Social dominance of female dairy goats and response to estrus synchronisation and superovulatory treatments. Appl Anim Behav Sci. 105: 115-121.

Ungerfeld R, Ramos MA, Gonzalez-Pensado SP. 2008. Ram effect: adult rams induce a greater reproductive response in anestrus ewes than yearling rams. Anim Reprod Sci. 103(34): 271-277.

Ungerfeld R. 2003. Reproductive responses of anestrous ewes to the introduction of rams. Phd thesis. Department of Clinical Chemistry Swedish University of Agricultural Sciences Uppsala, Sweden.
Vargas S, Larbi A, Sanchez M. 2007. Analysis of size and conformation of native Creole goat breeds and crossbreds used in smallholder agrosilvopastoral systems in Puebla, Mexico. Trop Anim Health Prod. 39(4): 279-286.

Veliz FG, Moreno S, Duarte G, Vielma J, Chemineau P, Poindron P, Malpaux B, Delgadillo JA. 2002. Male effect in seasonally anovulatory lactating goats depends on the presence of sexually active bucks, but not estrus females. Anim Reprod Sci. 72(3-4): 197-207.

Walkden-Brown SW, Bocquier F. 2000. Nutritional regulation of reproduction in goats. In: Gruner, L., Chabert, Y. (Eds.), Proceedings of the 7th International Conference on Goats. I: 389-395.

Wilson RT, Murayi T. 1988. Productivity of the small East African goat and its crosses with the Anglo-Nubian and the Alpine in Rwanda. Trop Anim Health Prod. 20 (4): 219-228.

Zhao Y, Zhang J, Wei H, Sun X, Mu B, Yu M, Wang L. 2010. Efficiency of methods applied for goat estrus synchronization in subtropical monsoonal climate zone of Southwest China. Trop Anim Health Prod. 42 (6): 1257-1262. 